\title{
Assessment of quality of life and its associated factors among people living with HIV/AIDS
}

\author{
Supriya Dhakne Palwe, Shivani Dargar, Pratik S. Tawri \\ Dr. Vasantrao Pawar Medical College, Hospital and Research Centre, Nashik, India
}

\begin{abstract}
Introduction: Acquired immunodeficiency syndrome (AIDS) has evolved from a mysterious illness to a global pandemic which has infected tens of millions of people. Assessing health-related quality of life (HQOL) is useful for documenting the patients' perceived burden of chronic disease, tracking changes in health over time, assessing the effects of treatment and quantifying the return on health care investment. The study aimed to assess the quality of life and its associated factors in patients with HIV/AIDS.
\end{abstract}

Material and methods: It was a hospital-based observational study conducted at the anti-retroviral therapy centre of the civil hospital, Nashik District. A total of 100 participants with confirmed HIV/ AIDS were included. The WHOQOL-HIV BREF instrument was used to assess the quality of life of people living with HIV/AIDS (PLHAs). Multivariate logical regression was used to study the factors affecting the quality of life of PLHAs.

Results: The mean scores of HQOL was highest in the domain of spirituality (15.99) followed by the physical domain (14.71), level of independence (14.45), social relationships (14.04), psychological domain (13.26), and environment (13.04), and the overall perception of quality of life and general health perception's scores were 13.28 and 12.84 .

Conclussions: These findings highlight the need for enhanced socio-psychosocial support and a better environment for improving the health-related quality of life among PLHAs.

HIV AIDS Rev 2018; 17, 2: 134-141 DOI: https://doi.org/10.5114/hivar.2018.76371

Key words: quality of life, HIV infection, acquired immunodeficiency syndrome, surveys and questionnaires, AIDS related opportunistic infections.

\section{Introduction}

Acquired immunodeficiency syndrome (AIDS) has evolved from a mysterious illness to a global pandemic which has infected tens of millions people [1]. Human immunodeficiency virus (HIV)/AIDS places an increasing burden on the health of the population, and causes further socio- economic problems for individuals, families, communities, NGOs and governments in many countries $[2,3]$. However, the recent advance in knowledge about the disease, better diagnostic methods, new treatments and strengthened HIV programs have provided great hope for HIV-positive people to live a long life [4]. In 2009, the National AIDS Control Organization (NACO) reported that there were 211 anti-
Address for correspondence: Dr. Supriya Dhakne Palwe, Dr. Vasantrao Pawar Medical College, Hospital and Research Centre, Vasantdada Nagar, Adgaon, 422003 Nashik, India, phone: +91 9272574480, e-mail: drsupriyadhakne@gmail.com
Article history:

Received: 30.06.2017

Received in revised form: 13.01.2018

Accepted: 16.01.2018

Available online: 21.05.2018
International Journal of HIV-Related Problems

HIV \& AIDS

R e vi e w 
retroviral therapy (ART) centers providing ART treatment free of cost to over 200000 PLHAs. ART can prolong the life span of PLHAs. However, there is no cure for HIV. HIV is increasingly considered a chronic disease. For a person living with HIV, this means having to cope up with a range of HIV-related symptoms for the entire life. Symptoms may be related to the infection itself, comorbid illnesses or iatrogenic effects from HIV-related medications.

Many HIV patients struggle with numerous social problems such as stigma, discrimination, poverty, depression, substance abuse, and cultural beliefs which can affect their quality of life (QOL) not only in the physical health aspect, but also from the mental and social health point of view and causes numerous problems [5]. The World Health Organization (WHO) has defined QOL as "individuals' perceptions of their position in life in the context of the culture and value systems in which they live and in relation to their goals, standards, expectations and concerns" [6].

Assessing health-related quality of life (HRQOL) is useful for documenting the patients' perceived burden of chronic disease, tracking changes in health over time, assessing the effects of treatment and quantifying the return on health care investment [7].

Many instruments for measuring QOL have been developed and described [8]. The WHO, in turn, has invested in the approach to QOL, having constructed the Quality of Life Assessment Group (The WHOQOL Group) for this. This initiative culminated in the creation of a generic QOL assessment instrument called the WHOQoL-100, developed in a multi-centric manner, with trans-cultural potential. Considering the particularities of living with AIDS, the WHOQOL-HIV was created, based on the above-mentioned instrument [9]. They have further developed its brief version (WHOQOL-HIV BREF) which contains a total of 31 questions divided into 6 domains and a general facet.

The aim of the study was to assess the quality of life of patients with HIV/AIDS using the WHOQOL-HIV BREF scale and to study the factors associated with the quality of life of people living with HIV/AIDS (PLHAs).

\section{Material and methods}

Type of study: Hospital-based observational study.

Study settings: The study was conducted at the anti-retroviral therapy (ART) centre of the civil hospital of a "Y" grade (Tier II) city of India.

Sample size: 100.

Sampling technique: Convenience sampling was used. The consecutive participants satisfying the eligibility criteria and willing to participate were enrolled until the desired sample size was achieved.

Selection criteria: inclusion criteria - 1) confirmed cases of HIV/AIDS, 2) age 18 years or above, irrespective of gender, 3) willing to participate; exclusion criteria - 1) the presence of any obvious co-morbid conditions not associated with HIV/AIDS, 2) documented cases of co-existing psychi- atric morbidity, 3) suffering from other systemic/metabolic/ endocrinal disorder.

Study design: The project proposal was approved by ICMR STS 2016. The study proposal was submitted to the Institutional Ethical Committee (IEC) and research was carried out after its approval. Permission from Maharashtra State AIDS Control Society (MSACS) was obtained. User agreement with the WHO was signed to use its Questionnaire WHOQOL-HIV BREF.

Before collecting data of patients from the ART, permission from the Civil Surgeon was taken.

Written informed consent was obtained. The respondents were informed about the objectives, purpose of the study and other relevant information of the study. Privacy and confidentiality were strictly maintained throughout. All other ethical issues were handled appropriately.

\section{Research instrument: WHOQOL-HIV BREF scale}

The questionnaire was originally developed by adopting the "31 items World Health Organization Quality of Life HIV BREF (WHOQOL-HIV BREF) instrument”. It is a multidimensional, conceptualized, generic, 31-item QOL instrument. It covers the respondent's perception of the overall quality of life within six broad domains: physical, psychological, level of independence, social, environmental and spiritual. There is also a general facet that measures the overall QOL and general health perceptions. The Physical domain describes 4 facets: pain and discomfort, energy and fatigue, sleep and rest, and symptoms related to HIV. The Psychological domain describes 5 facets: positive feelings, concentration, self-esteem, bodily image and appearance, and negative feelings. The Level of independence domain describes 4 facets: mobility, activities of daily living, dependence on medication and treatment, and work capacity. The Social relationships domain describes 4 facets: personal relationships, social support, sexual activity, and social inclusion. The Environment domain describes 8 facets: physical safety and security, home environment, financial resources, health and social care: accessibility and quality, opportunities for acquiring new information and skills, participation in and opportunities for recreation/leisure activities, physical environment, and transport. The Spirituality, religion and personal beliefs domain describes 4 facets: personal beliefs, forgiveness and blame, concerns about the future, and death and dying [10].

\section{Demographic and clinical information}

The socio-demographic and health variables collected were: gender; age; education level; work; average family income; place of residence; time since diagnosis of HIV seropositivity; clinical condition (asymptomatic/symptomatic/AIDS converted); ART use; duration of ART use; CD4 count, presence of opportunistic infections, etc. 
Table 1. Socio-demographic characteristics of study participants $(N=100)$

\begin{tabular}{|c|c|}
\hline Variables/Categories & $\begin{array}{c}\text { Frequency } \\
\text { (\% same as frequency) }\end{array}$ \\
\hline \multicolumn{2}{|l|}{ Sex } \\
\hline Male & 54 \\
\hline Female & 46 \\
\hline \multicolumn{2}{|l|}{ Age } \\
\hline$\leq 30$ years & 19 \\
\hline $31-40$ years & 43 \\
\hline $41-50$ years & 21 \\
\hline $51-60$ years & 11 \\
\hline$>60$ years & 6 \\
\hline \multicolumn{2}{|l|}{ Residence } \\
\hline Urban & 45 \\
\hline Rural & 50 \\
\hline Slum & 5 \\
\hline \multicolumn{2}{|l|}{ Marital status } \\
\hline Single & 12 \\
\hline Married & 74 \\
\hline Living as married & 01 \\
\hline Separated & 02 \\
\hline Divorced & 05 \\
\hline Widow & 06 \\
\hline \multicolumn{2}{|l|}{ Occupation } \\
\hline Profession & 16 \\
\hline Semi-professional & 02 \\
\hline Clerk, shop owner, farmer & 31 \\
\hline Skilled worker & 12 \\
\hline Semiskilled worker & 03 \\
\hline Unskilled worker & 22 \\
\hline Unemployed & 14 \\
\hline
\end{tabular}

\section{Mode of data collection}

The socio-demographic, clinical and quality of life data were obtained using the questionnaire by the personal interview method.

\section{Statistical analysis}

Descriptive statistical analysis of the socio-demographic and health questionnaire data was performed with the aid of the Statistical Package for the Social Sciences (SPSS) 20.0. For the analysis of the data from the WHOQOL-HIV BREF scale, the WHO user manual for the WHOQOL-HIV BREF scale was used for calculating the domain scores.

Generalized linear multivariate linear regression was used to test the association between the quality of life of PLHAs and various socio-demographic and disease-related factors.
Table 1. Cont.

\begin{tabular}{l|c}
\hline Variables/Categories & $\begin{array}{c}\text { Frequency } \\
\text { (\% same as frequency) }\end{array}$ \\
\hline Education & 23 \\
\hline Illiterate & 29 \\
\hline Primary & 28 \\
\hline Secondary & 13 \\
\hline University graduates & 7 \\
\hline Post-graduates & \\
\hline Average monthly income & 33 \\
\hline$<5000$ & 42 \\
\hline $5000-10000$ & 6 \\
\hline 10 000-15 000 & 19 \\
\hline 15 000 or above & \\
\hline Religion & 92 \\
\hline Hindu & 4 \\
\hline Muslim & 3 \\
\hline Buddha & 14 \\
\hline Jain & \\
\hline Loss of job & \\
\hline Yes & \\
\hline No & \\
\hline Presently employed or not & \\
\hline Yes & \\
\hline No & \\
\hline
\end{tabular}

\section{Results}

\section{Sample characteristics}

Table 1 shows the socio-demographic characteristics of the study participants. Of the 100 participants, more than half the respondents were male (54\%). They were mostly (43\%) between 31 and 40 years of age. Half of them were residing in rural areas and only $5 \%$ of them came from urban slums. Most of them were married (74\%) and there was a much lower percentage of separated (2\%) and divorced (5\%). Patients were from all kinds of occupations ranging from farmers and laborers to teachers and engineers. $14 \%$ of them were unemployed or suffered loss of a job. The average monthly income of $42 \%$ of them was only Rs 5000-10 000 and $33 \%$ of them earned less than Rs 5000 . Almost one quarter of respondents were illiterate (23\%) and much fewer of them have a post-graduate level of educational qualification (7\%). Most study participants were from the Hindu religion (92\%).

Table 2 shows disease- and treatment-related characteristics of the study participants. Only $15 \%$ of the respondents have not shared their serostatus with anyone and families of $77 \%$ of them were well acquainted with their serostatus. The majority of the respondents had been infected with this virus for a long time (more than 6 years). Only $2 \%$ of them 
Table 2. Disease- and treatment-related characteristics of study participants $(N=100)$

\begin{tabular}{|c|c|}
\hline Variables/Categories & Frequency (\%) \\
\hline \multicolumn{2}{|l|}{ Serostatus is known to } \\
\hline Nobody & 15 \\
\hline Spouse only & 5 \\
\hline Family only & 77 \\
\hline Family and friends & 3 \\
\hline \multicolumn{2}{|c|}{ Time since diagnosis of HIV } \\
\hline$\leq 1$ year & 23 \\
\hline $2-5$ years & 27 \\
\hline $6-10$ years & 40 \\
\hline$>10$ years & 10 \\
\hline \multicolumn{2}{|l|}{ Antiretroviral medication } \\
\hline$\leq 1$ year & 28 \\
\hline $2-5$ years & 26 \\
\hline $6-10$ years & 38 \\
\hline$>10$ years & 6 \\
\hline Not started & 2 \\
\hline \multicolumn{2}{|c|}{ CDC stage of HIV infection } \\
\hline Asymptomatic & 55 \\
\hline Symptomatic & 25 \\
\hline AIDS converted & 20 \\
\hline \multicolumn{2}{|c|}{ Current CD4 count (cells/mm³) } \\
\hline$<200$ & 22 \\
\hline $200-500$ & 53 \\
\hline$>500$ & 25 \\
\hline \multicolumn{2}{|l|}{ Opportunistic infections } \\
\hline Yes & 8 \\
\hline No & 92 \\
\hline \multicolumn{2}{|l|}{ Side effects of drugs } \\
\hline Yes & 20 \\
\hline No & 80 \\
\hline
\end{tabular}

were not receiving antiretroviral treatment. Most of them were asymptomatic (55\%) in the CDC stage of HIV infection and $20 \%$ AIDS converted. The majority of them (53\%) had a current CD4 count of more than 200 but less than 500 . Most of them had no opportunistic infection at all. Only $8 \%$ of them showed infection of pulmonary tuberculosis, fungal infection and oral thrush. Some of them even suffered from side effects of drugs (20\%) such as giddiness, headache, nausea, vomiting, stomach ache, rashes, and ulcers.

\section{Mean scores of quality of life in different domains}

Table 3 shows the mean scores for the overall perception of quality of life, general health perceptions and six domains.
Table 3. Mean scores for overall quality of life and general health perceptions and for six domains $(N=100)$

\begin{tabular}{l|l}
\hline Domains & Mean ( \pm SD) \\
\hline Physical & $14.71(3.32)$ \\
\hline Psychological & $13.26(3.32)$ \\
\hline Level of independence & $14.45(3.08)$ \\
\hline Social relationships & $14.04(3.07)$ \\
\hline Environment & $13.04(2.78)$ \\
\hline Spirituality/religion & $15.91(2.77)$ \\
\hline Overall perception of HQOL & $13.28(3.97)$ \\
\hline Overall general health perception & $12.84(4.45)$ \\
\hline
\end{tabular}

The mean scores of health-related quality of life (HQOL) was highest in the domain of spirituality (15.99) followed by the physical domain (14.71), level of independence (14.45), social relationships (14.04), psychological domain (13.26), environment (13.04) and the overall perception of quality of life and general health perception's scores were 13.28 and 12.84 .

Generalized linear multivariate linear regression was used to test the association between the quality of life of PLHAs and various socio-demographic and disease-related factors.

For this analysis, the 6 domain scores of the WHOQOLHIV BREF scale were taken as the dependent variables and the independent variables considered were socio-demographic (age, gender, education, marital status, place of residence, income, loss of job) and the HIV disease-related characteristics (clinical stage of HIV, years since diagnosis, years since ART, side effects, CD4 count, presence of opportunistic infections).

Tables $4 \mathrm{~A}$ and $4 \mathrm{~B}$ show the association of various sociodemographic and HIV disease characteristics with the quality of life of PLHAs. A significant association was found between the physical domain of QOL and presence of opportunistic infections. Domain 3 (Level of independence) showed a significant association with educational status and the number of years since ART was started. Also, the presence of side effects due to ART showed a significant association with the domain of social relationships. The environmental factors were significantly associated with the marital status. The number of years since ART was started was also associated with the spirituality/religion domain.

\section{Discussion}

This study demonstrated the importance of social demographic variables for quality of life for people dealing with HIV/AIDS. The largest portion of respondents affected were between 31 and 40 years of age and this finding is congruent with the report of Imam et al. [11] and Giri et al. [12].

The majority of the study participants were male, similar to the findings of report by Yadav et al. [13] and Giri et al. [12]. Most of them were from rural areas, which is similar to the study of Anusuya et al. [14] in Chennai. 
Table 4A. Generalized linear multivariate linear regression showing the association between socio-demographic factors affecting quality of life of people living with HIV/AIDS

\begin{tabular}{|c|c|c|c|c|}
\hline Sr. No. & Independent variable & Dependent variable & $p$-value & Statistical significance \\
\hline \multirow[t]{6}{*}{1} & \multirow[t]{6}{*}{ Age } & D-1 & 0.119 & NS \\
\hline & & D-2 & 0.676 & NS \\
\hline & & D-3 & 0.460 & NS \\
\hline & & D-4 & 0.222 & NS \\
\hline & & D-5 & 0.550 & NS \\
\hline & & D-6 & 0.786 & NS \\
\hline \multirow[t]{6}{*}{2} & \multirow[t]{6}{*}{ Gender } & D-1 & 0.811 & NS \\
\hline & & D-2 & 0.750 & NS \\
\hline & & D-3 & 0.326 & NS \\
\hline & & D-4 & 0.367 & NS \\
\hline & & D-5 & 0.330 & NS \\
\hline & & D-6 & 0.604 & NS \\
\hline \multirow[t]{6}{*}{3} & \multirow[t]{6}{*}{ Education } & D-1 & 0.254 & NS \\
\hline & & D-2 & 0.397 & NS \\
\hline & & D-3 & 0.018 & Statistically significant \\
\hline & & D-4 & 0.426 & NS \\
\hline & & D-5 & 0.447 & NS \\
\hline & & D-6 & 0.323 & NS \\
\hline \multirow[t]{6}{*}{4} & \multirow[t]{6}{*}{ Loss of job } & D-1 & 0.416 & NS \\
\hline & & D-2 & 0.673 & NS \\
\hline & & D-3 & 0.887 & NS \\
\hline & & D-4 & 0.391 & NS \\
\hline & & D-5 & 0.834 & NS \\
\hline & & D-6 & 0.822 & NS \\
\hline \multirow[t]{6}{*}{5} & \multirow[t]{6}{*}{ Income } & D-1 & 0.052 & NS \\
\hline & & D-2 & 0.095 & NS \\
\hline & & D-3 & 0.092 & NS \\
\hline & & D-4 & 0.983 & NS \\
\hline & & D-5 & 0.518 & NS \\
\hline & & D-6 & 0.758 & NS \\
\hline \multirow[t]{6}{*}{6} & \multirow[t]{6}{*}{ Residence } & D-1 & 0.057 & NS \\
\hline & & D-2 & 0.964 & NS \\
\hline & & D-3 & 0.052 & NS \\
\hline & & D-4 & 0.731 & NS \\
\hline & & D-5 & 0.338 & NS \\
\hline & & D-6 & 0.069 & NS \\
\hline \multirow[t]{6}{*}{7} & \multirow[t]{6}{*}{ Marital status } & D-1 & 0.458 & NS \\
\hline & & D-2 & 0.068 & NS \\
\hline & & D-3 & 0.499 & NS \\
\hline & & D-4 & 0.051 & NS \\
\hline & & D-5 & 0.039 & Statistically significant \\
\hline & & D-6 & 0.370 & NS \\
\hline
\end{tabular}

D-1 - Physical, D-2 - Psychological, D-3 - Level of independence, D-4-Social relationships, D-5 - Environment, D-6-Spirituality/Religion 
Table 4B. Generalized linear multivariate linear regression showing the association between HIV disease-related factors affecting quality of life of people living with HIV/AIDS

\begin{tabular}{|c|c|c|c|c|}
\hline Sr. No. & Independent variable & Dependent variable & $\mathrm{p}$-value & Statistical significance \\
\hline \multirow[t]{6}{*}{1} & \multirow[t]{6}{*}{ Clinical stage of HIV } & D-1 & 0.458 & NS \\
\hline & & D-2 & 0.268 & NS \\
\hline & & D-3 & 0.668 & NS \\
\hline & & D-4 & 0.397 & NS \\
\hline & & $\mathrm{D}-5$ & 0.065 & NS \\
\hline & & D-6 & 0.658 & NS \\
\hline \multirow[t]{6}{*}{2} & \multirow[t]{6}{*}{ Years since diagnosis } & D-1 & 0.390 & NS \\
\hline & & D-2 & 0.061 & NS \\
\hline & & D-3 & 0.471 & NS \\
\hline & & D-4 & 0.650 & NS \\
\hline & & D-5 & 0.781 & NS \\
\hline & & D-6 & 0.998 & NS \\
\hline \multirow[t]{6}{*}{3} & \multirow[t]{6}{*}{ Years since ART } & D-1 & 0.108 & NS \\
\hline & & D-2 & 0.217 & NS \\
\hline & & $\mathrm{D}-3$ & $0.018^{*}$ & Statistically significant \\
\hline & & D-4 & 0.235 & NS \\
\hline & & D-5 & 0.057 & NS \\
\hline & & D-6 & $0.004^{*}$ & Statistically significant \\
\hline \multirow[t]{6}{*}{4} & \multirow[t]{6}{*}{ Side effects } & D-1 & 0.262 & NS \\
\hline & & D-2 & 0.411 & NS \\
\hline & & D-3 & 0.533 & NS \\
\hline & & $\mathrm{D}-4$ & $0.018^{*}$ & Statistically significant \\
\hline & & D-5 & 0.068 & NS \\
\hline & & D-6 & 0.640 & NS \\
\hline \multirow[t]{6}{*}{5} & \multirow[t]{6}{*}{ CD4 count } & D-1 & 0.517 & NS \\
\hline & & D-2 & 0.402 & NS \\
\hline & & $\mathrm{D}-3$ & 0.671 & NS \\
\hline & & D-4 & 1.000 & NS \\
\hline & & D-5 & 0.518 & NS \\
\hline & & D-6 & 0.271 & NS \\
\hline \multirow[t]{6}{*}{6} & \multirow[t]{6}{*}{ Presence of opportunistic infections } & D-1 & $0.009^{*}$ & Statistically significant \\
\hline & & $\mathrm{D}-2$ & 0.112 & NS \\
\hline & & D-3 & 0.075 & NS \\
\hline & & D-4 & 0.074 & NS \\
\hline & & D-5 & 0.166 & NS \\
\hline & & $\mathrm{D}-6$ & 0.939 & NS \\
\hline
\end{tabular}

*Statistically significant, NS - Not significant

The socioeconomic and demographic characteristics of respondents of this study indicate that most of them were of low socio-economic status. This finding is consistent with several other studies of similar nature of various developing countries [15-18]. Almost one quarter of them were illiterate, which is similar to the findings of Anusuya et al. [14].
A majority of our patients were found to be asymptomatic in the present study, which is in agreement with the study by Bakiono et al. [19].

Table 5 shows the comparison of domain scores of WHOQOL-BREF in various studies with the present study. In the present study, the global score of quality of life was 85.41 . 
Table 5. Comparison of the quality of life domain scores of various studies with the present study

\begin{tabular}{l|c|c|c|c}
\hline \multirow{2}{*}{ Domains } & \multicolumn{4}{|c}{ Mean $( \pm \mathrm{SD})$} \\
\cline { 2 - 5 } & Present study & Imam et al. [11] & Anusuya et al. [14] & Liping et al. [21] \\
\hline Physical & $14.71(3.32)$ & $12.41(3.03)$ & 13.27 & 14.99 \\
\hline Psychological & $13.26(3.32)$ & $11.63(2.62)$ & 12.88 & 14.25 \\
\hline Level of independence & $14.45(3.08)$ & $12.21(2.28)$ & 14.40 & - \\
\hline Environment & $14.04(3.07)$ & $12.98(2.41)$ & 11.63 & 13.22 \\
\hline Spirituality/religion & $13.04(2.78)$ & $11.80(1.77)$ & 12.91 & 13.31 \\
\hline Overall perception of HQOL & $15.91(2.77)$ & $13.37(3.21)$ & 14.67 & - \\
\hline Overall general health perception & $13.28(3.97)$ & $11.85(3.74)$ & - & - \\
\hline
\end{tabular}

It is a slightly higher mean score than what was found in Burkina by Bakiono et al. [19]. A study conducted in Ethiopia by Deribew et al. [20] found a higher mean score of 91.9.

Liping et al. [21] reported that factors such as age, education, WHO clinical stage, ART adherence and CD4 count were significantly associated with various domains of QOL. In the present study, factors significantly associated with QOL were educational status, marital status, number of years since ART, side effects of ART and presence of opportunistic infections.

\section{Conclusions}

As HIV disease is among the most devastating of illnesses, having multiple and profound effects on all aspects of life, the evaluation of QOL is very important. A rise in the standard of living of people alone will not be enough to achieve happiness; there should be improvement in quality of life also. These findings highlight the need for enhanced socio-psychosocial support and a better environment for improving the health-related quality of life among PLHAs. It can be attained by offering comprehensive and integrated services to the PLHAs including primary medical care, substance abuse treatment, financial assistance, housing, food, child care and social sensitization. It is also important to underline the role of consultation-liaison psychiatry in the diagnosis and treatment of HIV and AIDS. Stress management interventions for HIV-infected persons are a promising approach to facilitate positive adjustment.

\section{Acknowledgement}

We sincerely acknowledge the Indian Council of Medical Research-Short term Studentship-2016 (ICMR-STS), MSACS, District AIDS Control Society, Nashik. We extend our gratitude towards Dean Dr. Mrunal Patil, Dr. Pradip Barde, Mr. Sunil Patil (Statistician), Central Research Laboratory, Department of Community Medicine, Ms. Shravya Kokkula, Ms. Charushila Sonawane of Dr. Vasantrao Pawar Medical College Hospital and Research Centre, and above all we are grateful to our study participants for their co-operation.

\section{Conflict of interest}

The authors declare no potential conflicts of interest with respect to the research, authorship, and/or publication of this article.

\section{References}

1. Park K. Park's Textbook of Preventive and Social Medicine. M/s. Banarasidas Bhanot Publishers, Jabalpur 2004; 343-344.

2. Walker N, Grassly NC, Garnett GP, et al. Estimating the global burden of HIV/AIDS: What do we really know about the HIV pandemic? Lancet 2004; 363: 2180-2185.

3. Beck EJ, Miners AH, Tolley K. The cost of HIV treatment and care: A global review. Pharmacoeconomics 2001; 19: 13-39.

4. Razera F, Ferreira J, Bonamigo RR. Factors associated with healthrelated quality-of-life in HIV-infected Brazilians. Int J STD AIDS 2008; 19: 519-523.

5. Aranda-Naranjo B. Quality of life in HIV-positive patient. J Assoc Nurses AIDS Care 2004; 15: 20-27.

6. Development of the World Health Organization WHOQOL-BREF quality of life assessment. The WHOQOL Group. Psychol Med 1998; 28: 551-558.

7. Basavarajaiah DM, B Narasimha Murthy, B Leelavathy, Maheshappa K. Assessment of Quality of Life of People Living With HIV/ AIDS In Karnataka State. Int J Sci Tech 2012; 1.

8. McDowell I, Newell C. Measuring Health: A Guide to Rating Scales and Questionnaires. $2^{\text {nd }}$ ed. Oxford University Press, New York 1996.

9. The WHOQoL HIV Group. Initial steps to developing the World health Organization's Quality of Life Instrument (WHOQoL) module for international assessment in HIV/Aids. AIDS Care 2003; 15: 347-357.

10. The WHOQoL HIV - BREF 2016. Available at: http://apps.who.int/ iris/bitstream/10665/77775/1/WHO_MSD_MER_Rev.2012.02_ eng.pdf?ua $=1$

11. Imam MH, Karim MR, Ferdous C, et al. Health related Quality of Life among the people living with HIV. Bangladesh Med Res Counc Bull 2011; 37: 1-6.

12. Giri S, Neupane M, Pant S, et al. Quality of life among people living with AIDS receiving ART: a study from Nepal. HIV AIDS (Auckl) 2013; 5: 277-282.

13. Yadav S. Perceived social support, hope, and quality of life of persons living with HIV/AIDS: a case study from Nepal. Qual Life Res 2010; 19: 157-166.

14. Anusuya GS, Udayashankar PM, Valan AS, et al. Quality of life of people living with HIV/AIDS: A cross sectional study in a community care centre in Chennai, South India. Int J Med Appl Sci 2013; 2: 346-355. 
15. Joint United Nations Programme on HIV/AIDS (UNAIDS). Report on Global HIV/AIDS Epidemic. Geneva, 2008.

16. Rüütel K, Pisarev H, Loit HM, Uuskula A. Factors influencing quality of life of people living with HIV in Estonia: a cross-sectional survey. J Int AIDS Soc 2009; 12: 13.

17. Nirmal B, Divya KR, Dorairaj VS, Venkateswaran K. Quality of life in HIV/AIDS patients: A cross-sectional study in south India. Indian J Sex Transm Dis 2008; 29: 15-17.

18. Wig N, Lekshmi, R, Pal H, et al. The impact of HIV/AIDS on the quality of life: a cross sectional study in north India. Indian J Med Sci 2006; 60: 3-12.

19. Bakiono F, Ouédraogo L, Sanou M, et al. Quality of life in people living with HIV: A cross sectional study in Ouagadougou, Burkina Faso. Springerplus 2014; 3: 372 .

20. Deribew A, Deribe K, Reda AA, et al. Change in quality of life: follow up study among patients with HIV infection with and without TB in Ethiopia. BMC Public Health 2013; 13: 408.

21. Liping M, Peng X, Haijiang L, et al. Quality of Life of People Living with HIV/AIDS: A Cross-Sectional Study in Zhejiang Province, China. PLoS One 2015; 10: e0135705. 